\title{
Hairy-cell leukaemia: an immunoperoxidase study of paraffin-embedded tissues
}

\author{
J. H. C. GOOI, G. F. BURNS, ${ }^{1,2}$ AND J. C. CAWLEY
}

From the University Departments of Immunology and Medicine, Leeds General Infirmary and Department of Haematological Medicine, University of Cambridge, UK

SUMMARY Paraffin sections of a variety of tissues from 12 patients with typical hairy-cell leukaemia (HCL) were stained for immunoglobulin heavy and light chains by the peroxidase-antiperoxidase (PAP) technique. Plasma cells were frequent, particularly in a lymph node from a severely infected patient. The reactive nature of the plasma cells of HCL was suggested by the fact that there was no restriction of light-chain expression, although viable hairy cells were shown to express monoclonal surface immunoglobulin. This, together with the absence by both light and electron microscopy of forms intermediate between hairy cells and plasma cells and the lack of ribosome-lamella complexes in the plasma cells, suggested that hairy cells do not differentiate into plasma cells. Although hairy cells are known to contain immunoglobulin, this was not demonstrable in hairy cells in the paraffin-embedded tissue. The PAP technique was also useful for demonstrating abundant splenic macrophages in HCL.

Hairy-cell leukaemia (HCL) is now widely regarded as a form of B-cell lymphoproliferative disorder in which the pathognomonic hairy cells in zeneral possess monoclonal surface (Fu et al., 1974; Haegert et al., 1974; Burns et al., 1978b; Jansen et al., 1979; Rieber et al., 1979) and cytoplasmic (Golde et al., 1977; Burns et al., 1978b; Jansen et al., 1979) immunoglobulin and can synthesise immunoglobulin in vitro (Rubin et al., 1969; Gordon and Smith, 1978; Cohen et al., 1979) and in vivo (Golde et al., 1977; Cawley et al., 1979).

In contrast to chronic lymphocytic leukaemia (CLL) - a closely related B-cell disorder-HCL is not usually associated with depressed levels of serum immunoglobulin (Golomb et al., 1978; Turner and Kjeldsberg, 1978), and plasma cells are frequently conspicuous (Pedio et al., 1975; Nanba et al., 1977; Braylan et al., 1978; Palutke et al., 1978). In the present study, the hairy cells and plasma cells in formalin-fixed, paraffin-embedded tissue are examined by the peroxidase-antiperoxidase

'Present address: Clinical Research Unit, The Walter and Eliza Hall Institute of Medical Research, Royal Melbourne Hospital, Victoria, Australia

'Supported by the Leukaemia Research Fund (UK).

Received for publication 28 June 1979
(PAP) technique in order to determine whether hairy cells can be shown to contain immunoglobulin by this technique, and to establish whether or not the flasma cells show restricted light expression and thus monoclonal involvement.

\section{Material and methods}

\section{PATIENTS}

A total of 12 patients with HCL was studied. All cases were clinically and haematologically typical, and in all instances the diagnosis was confirmed by the demonstration of typical splenic histology (Neiman et al., 1979) and by the finding of hairy cells with a typical ultrastructure (Katayama et al., 1972; Katayama and Schneider, 1977) and containing strong tartrate-resistant acid phosphatase (Yam et al., 1971).

\section{TISSUES}

All histological material was fixed in formol-saline. The tissues examined by the immunoperoxidase technique were as follows: spleen alone (9); spleen and rectal biopsy (1); rectal biopsy alone (1); and liver and lymph node (1).

All splenic and lymph node tissue was also examined by electron microscopy (Cawley and Hayhoe, 1973). 


\section{Immunoperoxidase staining}

The PAP technique of Sternberger $(1966 ; 1974)$ was performed on trypsinised (Curran and Gregory, 1978), paraffin-embedded sections, according to the method described by Mason and Taylor (1978). The various antisera were purchased from DAKOimmunoglobulins Ltd (through Mercia Brocades Ltd). The specificity of the rabbit anti-human heavy and light chain $(\gamma, \mu, \alpha, \kappa, \lambda)$ antisera used in the first layer was checked by specific staining of appropriate myeloma tissue.

A wide range of concentrations of first-layer antisera was tested. For optimal examination of plasma cells, dilutions of antiserum just inside the plateau region of staining were used. These were: $1 / 1000$ for anti-light chain sera, 1/800 for anti-G, and $1 / 400$ for anti-A and anti-M.

For the second layer of the method, swine anti-rabbit serum was used at a concentration of $1 / 50$, and for the third, the rabbit PAP conjugates were routinely used at a dilution of $1 / 100$. These reagents were also purchased from DAKO-immunoglobulins Ltd.

For control purposes, rabbit $\gamma$ glogulin was substituted for the specific anti-heavy and light chain antisera. Material stained in this way was always peroxidase negative, as was material in which the second and third layers were omitted.

\section{Scoring}

The number of peroxidase-positive plasma cells staining with each of the individual anti-heavy and light chain antisera was counted independently by two observers. At least 200 high-power ( $\times$ 1000) fields were scored with the aid of a $16 \mathrm{~mm}^{2}$ eyepiece graticule, and identical areas of serial sections of tissue stained with each antiserum were examined.

\section{Surface immunoglobulin (SIg)}

The SIg phenotype of hairy cells was determined by a rosette method using specific anti-heavy and light chain sera; full details of the method and specificity of the antisera are given elsewhere (Burns et al., 1978b; Cawley et al., 1978).

\section{Results}

IMMUNOPEROXIDASE STAINING

Hairy cells were consistently unstained by the PAP technique, even at dilutions of $1 / 50$ of the first layer of antibody (concentrations $>1 / 50$ produced diffuse staining in both anti- $\kappa$ and anti- $\lambda$, as well as antiheavy chain, preparations).

Labelled plasma cells were identifiable in all tissues examined: in the spleen, plasma cells were seen scattered throughout the splenic parenchyma but were particularly numerous around blood vessels. The results of the scoring of splenic plasma cells are set out in the Table. IgG plasma cells predominated in all but two cases where IgA plasma cells were conspicuous. A polyclonal (mixed $\kappa$ and $\lambda$ ) pattern of staining was observed in all instances.

A similar polyclonal pattern of plasma-cell staining was observed in rectal, lymph node, and liver material, where plasma cells were again numerous. In the rectal biopsies, IgA-containing plasma cells exceeded IgG plasma cells, while in the lymph node IgG plasma cells were more numerous; in both rectal and lymph node tissue, IgM plasma cells were rarely seen. In liver, the plasma cells were confined to the portal tracts, and IgG plasma cells predominated.

Macrophages containing granular polyclonal immunoglobulin staining were consistently observed in all tissues. The frequency of macrophages was

Table PAP staining of plasma cells in $H C L$

\begin{tabular}{|c|c|c|c|c|c|c|c|c|c|c|c|c|c|c|c|c|c|}
\hline \multirow[t]{2}{*}{ Patient } & \multicolumn{5}{|c|}{ Plasma cells } & \multicolumn{2}{|l|}{ Total } & \multicolumn{5}{|c|}{$\%$ Total plasma cells } & \multirow[t]{2}{*}{ Tissue } & \multirow{2}{*}{$\begin{array}{l}\text { SIg phenotype of splenic } \\
\text { hairy cells }\end{array}$} & \multicolumn{3}{|l|}{ Serum } \\
\hline & $\kappa$ & $\lambda$ & $G$ & $A$ & $M$ & $L$ & $\boldsymbol{H}$ & $\kappa$ & $\lambda$ & $G$ & $A$ & $M$ & & & $\begin{array}{l}\operatorname{Ig} G \\
(g / I)\end{array}$ & $\begin{array}{l}\operatorname{IgA} \\
(g / 1)\end{array}$ & $\begin{array}{l}\lg M \\
(g / I)\end{array}$ \\
\hline $\begin{array}{l}\text { AB } \\
\text { PS } \\
\text { HR } \\
\text { HI } \\
\text { HOR } \\
\text { WE } \\
\text { NW } \\
\text { DC } \\
\text { LP } \\
\text { MHe } \\
\text { MH }\end{array}$ & $\begin{array}{r}46 \\
51 \\
40 \\
40 \\
18 \\
17 \\
53 \\
80 \\
27 \\
7 \\
687\end{array}$ & $\begin{array}{r}49 \\
45 \\
48 \\
24 \\
29 \\
20 \\
50 \\
38 \\
16 \\
16 \\
486\end{array}$ & $\begin{array}{r}91 \\
43 \\
56 \\
33 \\
36 \\
24 \\
74 \\
91 \\
26 \\
10 \\
651\end{array}$ & $\begin{array}{r}44 \\
57 \\
29 \\
16 \\
7 \\
12 \\
25 \\
17 \\
14 \\
21 \\
194\end{array}$ & $\begin{array}{r}2 \\
4 \\
6 \\
1 \\
4 \\
5 \\
7 \\
6 \\
6 \\
1 \\
14\end{array}$ & $\begin{array}{r}95 \\
96 \\
88 \\
64 \\
47 \\
37 \\
103 \\
118 \\
43 \\
23 \\
1173\end{array}$ & $\begin{array}{r}137 \\
104 \\
91 \\
50 \\
47 \\
41 \\
106 \\
114 \\
46 \\
32 \\
859\end{array}$ & $\begin{array}{l}48 \\
53 \\
45 \\
63 \\
38 \\
46 \\
51 \\
68 \\
63 \\
30 \\
59\end{array}$ & $\begin{array}{l}52 \\
47 \\
55 \\
38 \\
62 \\
54 \\
49 \\
32 \\
37 \\
70 \\
41\end{array}$ & $\begin{array}{l}66 \\
41 \\
62 \\
66 \\
77 \\
59 \\
70 \\
80 \\
57 \\
31 \\
76\end{array}$ & $\begin{array}{l}32 \\
55 \\
32 \\
32 \\
15 \\
29 \\
24 \\
15 \\
30 \\
66 \\
23\end{array}$ & $\begin{array}{r}1 \\
4 \\
6 \\
2 \\
9 \\
12 \\
7 \\
5 \\
13 \\
3 \\
2\end{array}$ & $\begin{array}{l}\text { Spleen } \\
\text { Spleen } \\
\text { Spleen } \\
\text { Spleen } \\
\text { Spleen } \\
\text { Spleen } \\
\text { Spleen } \\
\text { Spleen } \\
\text { Spleen } \\
\text { Spleen } \\
\text { Lymph } \\
\text { node }\end{array}$ & $\begin{array}{l}\text { G } \kappa \\
\text { DGM } \lambda \\
\text { DGMA } \kappa \\
\text { DGM } \kappa \\
\text { G } \lambda \\
\text { DGM } \lambda \\
\text { G } \kappa^{*} \\
\text { G } \kappa \\
\text { DGM } \lambda \\
-\kappa^{*} \\
\mathbf{G} \kappa^{*}\end{array}$ & $\begin{array}{c}10 \cdot 8 \\
12 \cdot 1 \\
8 \cdot 2 \\
\overline{14 \cdot 2} \\
14 \cdot 2 \\
\overline{11} \cdot 7 \\
12 \cdot 7 \\
22 \cdot 2 \\
13 \cdot 5\end{array}$ & $\begin{array}{l}1 \cdot 5 \\
4 \cdot 3 \\
2 \cdot 0 \\
- \\
3 \cdot 4 \\
2 \cdot 6 \\
- \\
2 \cdot 3 \\
1 \cdot 3 \\
10 \cdot 2 \\
4 \cdot 0\end{array}$ & $\begin{array}{l}0.5 \\
0.2 \\
0.7 \\
- \\
1.2 \\
1.2 \\
- \\
0.6 \\
0.7 \\
2.8 \\
0.7\end{array}$ \\
\hline
\end{tabular}

* Hairy cell SIg phenotype determined on peripheral blood hairy cells; this is usually identical with that of splenic hairy cells. - not done. 
usually less than that of plasma cells, and when plasma cells were infrequent (HOR, WE, and MHE) macrophages were rare.

\section{Discussion}

The present immunoperoxidase study of paraffinembedded tissues failed to demonstrate specific intracytoplasmic immunoglobulin staining of hairy cells but did show numerous strongly reactive plasma cells in a variety of organs.

Although hairy cells have been shown to contain intracytoplasmic immunoglobulin by both immunofluorescent (Burns et al., 1978b; Jansen et al., 1979) and immunoprecipitation methods (Gordon and Smith, 1978), the levels of synthesis are much lower than in plasma cells. Nevertheless, since the PAP technique employed is highly sensitive (Sternberger, 1974), some hairy cell staining might have been expected, particularly since the hairy cells from some of our patients were shown to contain intracytoplasmic immnooglobulin by direct immunofluorescence (Burns et al., 1978b). The failure of hairy cells in paraffin sections to stain is probably attributable to damage to antigenic determinants on the small amounts of intrinsic immunoglobulin present. This may be the result of denaturation, masking, or loss during histological processing, but is not attributable to lack of sensitivity of the PAP technique itself since we found that acetone-fixed preparations of isolated hairy cells contain immunoglobulin by this technique (data not shown).

Plasma cells in paraffin sections were, however, readily shown to contain immunoglobulin and it was confirmed that these cells are frequently numerous in a range of organs in HCL. In the spleen, the plasma cells were shown to be particularly numierous around blood vessels and were also scattered throughout the splenic pulp. Plasma cells were especially numerous in the only lymph node examined, and their reactive nature was suggested by the fact that the patient had overwhelming bacterial infection.

Light-chain staining of plasma cells in all tissues showed no evidence of isotype restriction and therefore no evidence of clonal involvement. This is in contrast to those non-Hodgkin's lymphomas with plasmacytoid differentiation (Brouet and Seligmann, 1977; Taylor, 1978) where both the PAP and immunofluorescent techniques have clearly demonstrated that the plasmacytoid cells contain the same immunoglobulin isotypes as the malignant lymphoid clone from which they presumably derive. Even in CLL, it has been shown that the neoplastic lymphocytes can, under certain conditions, mature into plasma cells of the same idiotype (Fu et al.,
1978). In the present study, it is demonstrated that there is no such plasmacytoid differentiation of hairy cells in vivo and that the plasma cells present are reactive. Moreover, no cells with an appearance intermediate between that of hairy cells and plasma cells were observed by either PAPstaining or electron microscopy. Also, despite the fact that myelomatous plasma cells can contain the ribosome-lamella (R-L) complexes so characteristic of hairy cells (Brunning and Parkin, 1975), the plasma cells of HCL were never seen to contain R-L complexes in any of our patients even when the complexes were numerous in the hairy cells.

Our PAP results showed no evidence of depression of plasma cells containing the light-chain type of the hairy cells clone. This finding contrasts with those in myeloma, where intestinal plasma cells with the light-chain type of the myeloma cells are reduced in number (Leonard et al., 1979). Our results are therefore in accord with the fact that HCL, unlike myeloma, is not usually associated with immuneparesis (Golomb et al., 1978; Turner and Kjeldsberg, 1978). In this regard it is of interest that in the two patients in whom IgA plasma cells predominated in the spleen high levels of serum IgA were detected.

Finally, the PAP technique allowed ready recognition of tissue macrophages since these contained distinctive granular immunoglobulin staining (representing phagocytosed extrinsic immunoglobulin), and this allowed us to confirm that, despite the peripheral monocytopenia of HCL (Seshadri et al., 1976; Burns et al., 1978a), tissue macrophages are plentiful in the disease (Nanba et al., 1977; Palutke et al., 1978).

We thank Dr B. E. Roberts, Dr D. G. Scott, and Professor G. Gowland for advice and encouragement. We are grateful to Miss $\mathbf{H}$. Collingwood for typing the manuscript.

\section{References}

Braylan, R. C., Jaffe, E. S., Triche, T. J., Nanba, K., Fowlkes, B. J., Metzger, H., Frank, M. M., Dolan, M. S., Yee, C. L., Green, I., and Berard, C. W. (1978). Structural and functional properties of the 'hairy' cells of leukemic reticuloendotheliosis. Cancer, 41, 210-227.

Brouet, J. C., and Seligmann, M. (1977). Chronic lymphocytic leukaemia as an immunoproliferative disorder. Clinics in Haematology, 6, 169-184.

Brunning, R. D., and Parkin, J. (1975). Ribosome-lamella complexes in neoplastic haematopoietic cells. American Journal of Pathology, 79, 565-572.

Burns, G. F., Cawley, J. C., Higgy, K. E., Barker, C. R., 
Edwards, M., Rees, J. K. H., and Hayhoe, F. G. J. (1978a). Hairy-cell leukaemia: a B-cell neoplasm with a severe deficiency of circulating normal B lymphocytes. Leukemia Research, 2, 33-40.

Burns, G. F., Cawley, J. C., Worman, C. P., Karpas, A., Barker, C. R., Goldstone, A. H., and Hayhoe, F. G. J. (1978b). Multiple heavy chain isotypes on the surface of the cells of hairy-cell leukemia. Blood, 52, 1132-1147.

Cawley, J. C., Burns, G. F., Bevan, A., Worman, C. P., Smith, J. L., Gray, L., Barker, C. R., and Hayhoe, F. G. J. (1979). Typical hairy-cell leukaemia with IgGK paraprotein (abstract), British Journal of Haematology, 41, 616.

Cawley, J. C., Burns, G. F., Nash, T. A., Higgy, K. E., Child, J. A., and Roberts, B. E. (1978). Hairy-cell leukemia with T-cell features. Blood, 51, 61-69.

Cawley, J. C., and Hayhoe, F. G. J. (1973). Ultrastructure of Haemic Cells. Saunders, London and Philadelphia.

Cohen, H. J., George, E. R., and Kremer, W. B. (1979). Hairy cell leukemia: cellular characteristics including surface immunoglobulin dynamics and biosynthesis. Blood, 53, 764-775.

Curran, R. C., and Gregory, J. (1978). Demonstration of immunoglobulin in cryostat and paraffin sections of human tonsil by immunofluorescence and immunoperoxidase techniques. Journal of Clinical Pathology, 31, 974-983.

Fu, S. M., Chiorazzi, N., Kunkel, H. G., Halper, J. P., and Harris, S. R. (1978). Induction of in vitro differentiation and immunoglobulin synthesis of human leukemic B lymphocytes. Journal of Experimental Medicine, 148, 1570-1578.

Fu, S. M., Winchester, R. J., Rai, K. R., and Kunkel, H. G. (1974). Hairy cell leukemia: proliferation of a cell with phagocytic and B-lymphocyte properties. Scandinavian Journal of Immunology, 3, 847-851.

Golde, D. W., Stevens, R. H., Quan, S. G., and Saxon, A. (1977). Immunoglobulin synthesis in hairy cell leukaemia. British Journal of Haematology, 35, 359-365.

Golomb, H. M., Catovsky, D., and Golde, D. W. (1978). Hairy cell leukemia. Annals of Internal Medicine, 89, 677-683.

Gordon, J., and Smith, J. L. (1978). Free immunoglobulin light chain synthesis by neoplastic cells in leukaemic reticuloendotheliosis. Clinical and Experimental Immunology, 31, 244-250.

Haegert, D. G., Cawley, J. C., Collins, R. D., Flemans, R. J., and Smith, J. L. (1974). Leukaemic reticuloendotheliosis: a morphological and immunological study of four cases. Journal of Clinical Pathology, 27, 967-972.

Jansen, J., Schuit, H. R. E., van Zwet, T. L., Meijer, C. J. L. M., and Hijmans, W. (1979). Hairy-cell leukaemia: a B-lymphocytic disorder. British Journal of Haematology, 42, 21-33.

Katayama, I., Li, C. Y., and Yam, L. T. (1972). Ultrastructural characteristics of the 'hairy cells' of leukemic reticuloendotheliosis. American Journal of Pathology, 67, 361-370.

Katayama, I., and Schneider, G. B. (1977). Further ultrastructural characterization of hairy cells of leukemic reticuloendotheliosis. American Journal of Pathology, 86, 163-174.

Leonard, R. C. F., Maclennan, I, C. M., Smart, Y., Vanhegan, R. I., and Kuzick, J. (1979). Light chain isotype-associated suppression of normal plasma cell numbers in patients with multiple myeloma. International Journal of Cancer (In press).

Mason, D. Y., and Taylor, C. R. (1978). Distribution of transferrin, ferritin, and lactoferrin in human tissues, Journal of Clinical Pathology, 31, 316-327.

Nanba, K., Jaffe, E. S., Soban, E. J., Braylan, R. C., and Berard, C. W. (1977). Hairy cell leukemia: enzyme histochemical characterization, with special reference to splenic stromal changes. Cancer, 39, 2323-2336.

Neiman, R. S., Sullivan, A. L., and Jaffe, R. (1979). Malignant lymphoma simulating leukemic reticuloendotheliosis. Cancer, 43, 329-342

Palutke, M., Weise, R. W., Tabaczka, P., Varadachari, C., and Axelrod, A. (1978). Hairy cells and macrophages. A comparative study. Laboratory Investigation, 39, 267-280.

Pedio, G., Rüttner, J. R., Spycher, M. A., and Gut, D. (1975). Virus-bearing plasma cells in peripheral blood of a patient with "hairy cell leukemia". Acta Haematologica, 54, 297-305.

Rieber, E. P., Hadam, M. R., Linke, R. P., Saal, J. G., Riethmüller, G., von Heyden, H. W., and Waller, H. D. (1979). Hairy cell leukaemia: surface markers and functional capacities of the leukaemic cells analysed in eight patients. British Journal of Haematology, 42, 175-188.

Rubin, A. D., Douglas, S. D., Chessin, L. N., Glade, P. R., and Dameshek, W. (1969). Chronic reticulolymphocytic leukemia: reclassification of 'leukemic reticuloendotheliosis' through functional characterization of the circulating mononuclear cells. American Journal of Medicine, 47, 149-162.

Seshadri, R. S., Brown, E. J., and Zipursky, A. (1976). Leukemic reticuloendotheliosis. A failure of monocyte production. New England Journal of Medicine, 295, 181184.

Sternberger, L. A. (1966). Electron microscopic immunocytochemistry: a review. Journal of Histochemistry and Cytochemistry. 15, 139-159.

Sternberger, L. A. (1974). Immunocytochemistry. PrenticeHall, Englewood Cliffs, N.J.

Taylor, C. R. (1978). Immunocytochemical methods in the study of lymphoma and related conditions. Journal of Histochemistry and Cytochemistry, 26, 496-512.

Turner, A., and Kjeldsberg, C. R. (1978). Hairy cell leukemia: a review. Medicine, 57, 477-499.

Yam, L. T., Li, C. Y., and Lam, K. W. (1971). Tartrateresistant acid phosphatase isoenzyme in the reticulum cells of leukemic reticuloendotheliosis. New England Journal of Medicine, 284, 357-360.

Requests for reprints to: Dr J. C. Cawley, Department of Haematology, University College Hospital, Gower Street, London WC1E 6JJ, UK. 